\title{
Ephrin Type-B Receptor 4
}

National Cancer Institute

\section{Source}

National Cancer Institute. Ephrin Type-B Receptor 4. NCI Thesaurus. Code C113832.

Ephrin type-B receptor 4 (987 aa, $\sim 108 \mathrm{kDa}$ ) is encoded by the human EPHB4 gene. This protein plays a role in ephrin-B binding, tyrosine phosphorylation, and signal transduction. 